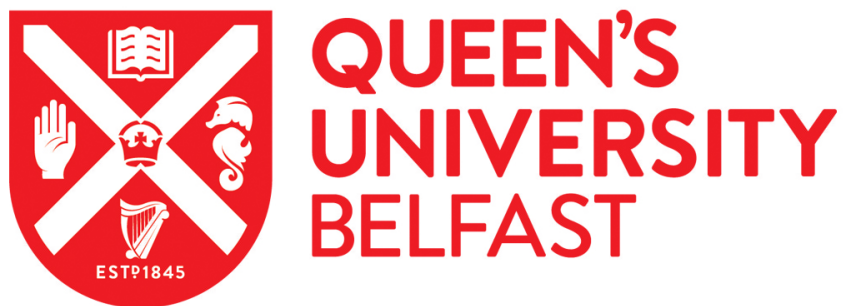

\section{The organizational ecology of ethnic cleavages: The nonlinear effects of ethnic diversity on party system fragmentation}

Raymond, C. D. (2015). The organizational ecology of ethnic cleavages: The nonlinear effects of ethnic diversity on party system fragmentation. Electoral Studies, 37, 109-119. https://doi.org/10.1016/j.electstud.2014.12.001

\author{
Published in: \\ Electoral Studies
}

Document Version:

Peer reviewed version

Queen's University Belfast - Research Portal:

Link to publication record in Queen's University Belfast Research Portal

Publisher rights

(c) 2014 Elsevier Ltd.

This is the author's version of a work that was accepted for publication in Electoral Studies. Changes resulting from the publishing process, such as peer review, editing, corrections, structural formatting, and other quality control mechanisms may not be reflected in this document. Changes may have been made to this work since it was submitted for publication. A definitive version was subsequently published in Electoral Studies, [VOL 37, March 2015] doi:10.1016/j.electstud.2014.12.001

\section{General rights}

Copyright for the publications made accessible via the Queen's University Belfast Research Portal is retained by the author(s) and / or other copyright owners and it is a condition of accessing these publications that users recognise and abide by the legal requirements associated with these rights.

Take down policy

The Research Portal is Queen's institutional repository that provides access to Queen's research output. Every effort has been made to ensure that content in the Research Portal does not infringe any person's rights, or applicable UK laws. If you discover content in the Research Portal that you believe breaches copyright or violates any law, please contact openaccess@qub.ac.uk. 
The organizational ecology of ethnic cleavages:

\title{
The nonlinear effects of ethnic diversity on party system fragmentation
}

\author{
Christopher D. Raymond \\ Lecturer in Politics \\ Queen's University Belfast \\ C.Raymond@qub.ac.uk \\ 25 University Square \\ Department of Politics, International Studies, and Philosophy \\ Queen's University Belfast \\ Belfast, United Kingdom \\ BT7 1PB
}

\section{Key Words}

party systems; social cleavages; ethnic diversity; organizational ecology

\begin{abstract}
The conventional wisdom regarding party system fragmentation assumes that the effects of electoral systems and social cleavages are linear. However, recent work applying organizational ecology theories to the study of party systems has challenged the degree to which electoral system effects are linear. This paper applies such concepts to the study of social cleavages. Drawing from theories of organizational ecology and the experience of many ethnically diverse African party systems, I argue that the effects of ethnic diversity are nonlinear, with party system fragmentation increasing until reaching moderate levels of diversity before declining as diversity reaches extreme values. Examining this argument cross-nationally, the results show that accounting for nonlinearity in ethnic diversity effects significantly improves model fit.
\end{abstract}




\section{Introduction}

The conventional wisdom regarding party systems maintains that the number of parties is determined by the interaction of electoral systems and social cleavages (Duverger, 1954; Ordeshook and Shvetsova, 1994; Amorim Neto and Cox, 1997; Clark and Golder, 2006; Singer and Stephenson, 2009). According to this literature, more proportional electoral systems produce greater party system fragmentation when cleavage diversity increases. Implied, though rarely stated so explicitly, is the notion that increases in party system fragmentation resulting from increased cleavage diversity are relatively linear.

Recent work has questioned the degree to which this interaction effect is linear. Noting that most work has employed the logged functional form of district magnitudewhich implies a nonlinear relationship to party system fragmentation-instead of the linear functional form, Lowery et al. (2010) argue that the relationship between electoral system proportionality and party system fragmentation is nonlinear. Drawing from organizational ecology theories, they maintain that at higher levels of proportionality, competition for voters becomes too intense and the availability of resources too scarce to support additional political parties; thus, increases in party system fragmentation level off at the highest levels of electoral system proportionality.

This paper builds on these criticisms of the linear assumptions made by previous research, though focusing specifically on the effect of ethnic diversity. I examine ethnicity in large part because ethnic diversity has been the cleavage measure of choice in most studies examining the interaction of electoral systems and social cleavages. Drawing from organizational ecology theories, I argue that the effect of ethnic cleavages is nonlinear. While increases in ethnic diversity will produce increases in party system fragmentation at moderate levels of ethnic diversity, extreme ethnic diversity will be associated with lower levels of party system fragmentation than a linear relationship would imply. This is because 
extreme ethnic diversity leaves few ethnic groups with bases of support sizable enough to sustain parties with enough votes to compete for control of the government and/or to influence policy favorable to their ethnic groups. Instead, parties in contexts of extreme ethnic diversity have to (and often do) build broad multiethnic coalitions if they want to compete for control of the government and/or increase their chances of influencing policy.

In this paper, I examine the linearity of the relationship between ethnic diversity and party system fragmentation. Specifically, I examine whether this organizational ecology argument helps to explain the patterns of party system fragmentation cross-nationally. Applied to a data set that includes elections from countries around the world, this argument helps to explain the nonlinear relationship between ethnic diversity and party system fragmentation.

\section{Ethnic Diversity and Party System Fragmentation}

As noted above, most previous research regarding the relationship between ethnic diversity and party system fragmentation — which focuses primarily on party systems in Western democracies - maintains that the effects of ethnic diversity on party system fragmentation are roughly linear (e.g. Ordeshook and Shvetsova, 1994; Amorim Neto and Cox, 1997; Clark and Golder, 2006). However, if one is to explain the relationship between ethnicity and party systems cross-nationally, one must understand the effects of ethnicity within the context of Sub-Saharan African elections and how the relationship between ethnic diversity and party system fragmentation seen in African polities fits with the patterns seen elsewhere. Much of the research on African party systems has focused on the degree to which the patterns of party system fragmentation in Africa are different - that is, the degree to which the effects of institutions and social cleavages on African party systems match the findings of previous research. For instance, some work (Mozaffar, Scarritt, and Galaich, 2003; though see also Brambor, Clark, and Golder, 2007a) has argued that institutions, ethnic 
cleavages, and the interaction between the two types of variables do not have the same effects on party system fragmentation as those seen in previous research focusing on non-African party systems.

The notion that African party systems are distinct is seen particularly clearly with regard to the low levels of party system fragmentation and high frequency of one-party dominance (Bogaards, 2004). Contrary to the fears of those like Horowitz (1985), the adoption of PR in some African countries has not resulted in highly fragmented party systems, as low party system fragmentation pervades the continent, occurring under PR just as it does under majoritarian electoral systems (Erdmann and Basedau, 2008). Some claim that low party system fragmentation in African countries occurs in a context of high electoral volatility, with one dominant party and several inconsequential opposition parties that enter and exit the party system from one election to the next (Mozaffar and Scarritt, 2005; though see also Bogaards, 2008), while others claim that most African party systems are either becoming more institutionalized or have been highly institutionalized from the outset of democratic elections (Kuenzi and Lambright, 2001; Lindberg, 2007). Regardless one's interpretation of the effect and importance of electoral volatility, the consensus remains that many African party systems are characterized by low party system fragmentation, despite high levels of ethnic diversity in several of those countries.

Unlike the conventional wisdom, which has assumed that greater ethnic diversity produces greater party system fragmentation, some literature focusing on African party systems argues that extremely high levels of ethnic diversity actually serve to limit party system fragmentation. As part of the "Big Man" style of politics, African politicians try to build the largest possible coalitions of supporters as a means of demonstrating their power and prestige, as well as to maintain electoral stability and security (Hyden, 2006: 103-104). Given the high degree of ethnic diversity in many African polities, many African politicians 
often call for national unity in ways that appeal to multiple ethnic groups through what are termed ethnic congress parties instead of appealing to voters along specific ethnic-group lines as ethnic-based parties do. ${ }^{1}$ As a result, party system fragmentation is low in countries with extremely high levels of ethnic diversity (Erdmann and Basedau, 2008).

A good example of how low levels of party system fragmentation can occur despite high levels of ethnic fragmentation is the case of South Africa. Defined in ethnic terms, South Africa's population is quite diverse: in addition to whites (who can be divided further into Dutch Afrikaners and English) and Indians (those whose ancestry traces back to the Indian subcontinent), South Africa's black population is divided into several ethnic groups, including (to name a few) the Zulu, Xhosa, Pedi, Tswana, Sotho, Tsonga, Swazi, Venda, and Ndebele. This fragmentation makes South Africa one of the most ethnically diverse countries in the world: using data from Fearon (2003), the effective number of ethnic groups in South Africa (i.e. calculating ethnic fragmentation in the same way as party system fragmentation using the effective number of parties: see Laakso and Taagepera, 1979) is 8.3. With such considerable ethnic diversity, and basing expectations regarding party system fragmentation in South Africa on the conventional wisdom, one would expect that South Africa's party system would be highly fragmented as well. Despite considerable ethnic diversity and using a highly proportional electoral system, party system fragmentation in South Africa is actually quite low: the effective number of electoral parties in 1994 and 1999 was 2.24 and 2.16, respectively.

While several prominent opposition parties exist, South Africa's party system revolves predominantly around the African National Congress (ANC), which has won no less than 60 percent of the vote since it was first allowed to contest elections in 1994. Instead of party leaders mobilizing voters along ethnic lines, the ANC has chosen to mobilize support along racial lines from voters belonging to most of the black African ethnic groups. This has 
rendered each South African election into a "racial census," with political behavior strongly influenced by the parties' racial cues and party support dividing clearly along racial lines (Ferree, 2006). Because black South Africans make up an overwhelming majority of the population, this has virtually guaranteed the ANC a dominant position for the foreseeable future.

ANC leaders have chosen to operate as an ethnic congress party in order to prevent the proliferation of ethnic-based parties - and the potential ethnic conflict resulting from this fragmentation - that would substantially weaken the ANC's ability to govern, which in turn might have threatened the position of black South Africans vis-à-vis whites (Piombo, 2005). Despite attempts by some ethnic groups to forge ethnic-based parties — as with the case with the Inkatha Freedom Party, which caters primarily to Zulu voters-most black South Africans have responded to the ANC's pan-racial appeals. (Even Zulu voters appear to be heeding such appeals in recent elections: winning more than 10 percent of the vote in 1994 , the Inkatha Freedom Party was reduced to less than three percent of the vote in the 2014 election.) Thus, the case of South Africa illustrates how party leaders in highly diverse societies will make broad appeals across ethnic lines in order to pursue power, and how this strategy results in levels of party system fragmentation that are drastically smaller than one would expect given its level of ethnic diversity.

While the efforts of party leaders to make broad ethnic congress-type appeals have received a lot of attention from researchers seeking to explain the dominant party systems of several African countries, there is reason to believe that the constraining effects of high ethnic diversity on party system fragmentation may actually be part of a broader crossnational phenomenon. For instance, the experience of countries like India-with its history of dominance by the Congress Party, which has appealed to a broad range of ethnic groups in order to prevent party fragmentation along ethnic lines - also shows how high levels of ethnic 
diversity may constrain party system fragmentation, resulting in a nonlinear relationship between ethnic diversity and party system fragmentation when observing party systems cross-nationally. Given that elites in other ethnically diverse countries have also mobilized support through ethnic congress parties instead of more particularistic ethnic-based parties, this suggests that the findings of low levels of party system fragmentation in highly diverse countries may not be unique to African party systems. Moreover, this shows that a generalizable explanation is needed to account for the nonlinear relationship that one observes between ethnic diversity and party system fragmentation when viewing party systems in cross-national perspective.

\section{The Organizational Ecology of Ethnic Cleavages}

In order to provide a generalizable explanation of the relationship between ethnic and party system fragmentation that can bridge the gap between the findings from developed democracies and those from Africa and elsewhere with more extreme levels of ethnic diversity, I argue that the relationship between ethnic diversity and party system fragmentation is nonlinear. In order to explain this nonlinear relationship, I refer to several theories of organizational ecology (Hannan and Freeman, 1977; Singh and Lumsden, 1990). Organizational ecology has been applied to a wide range of organizations, including political organizations and institutions, such as interest groups (e.g. Lowery and Gray, 1995; Nownes, 2004, 2010; Stretesky, Huss, and Lynch, 2012), electoral systems (Lowery et al., 2010), and political parties (Lowery et al., 2013). At present, it remains to be applied to social cleavages.

One notion known as density dependence maintains that the emergence and survival of organizations (such as political parties) depends upon the availability of resources capable of creating and sustaining such organizations (Delacroix and Carroll, 1983; Hannan and Carroll, 1992). Similar to population ecology in biology, the evolution of organizations is 
determined by the competition for those scarce resources, which operates in a process of natural selection. The number and viability of organizations will increase as the resources capable of sustaining them increase. However, because these resources are usually finite, competition for scarce resources begins to place limits on the entry of new organizations without the death (i.e. exit) of an old organization. When the entry of a new organization intensifies competition for resources, this will produce a decline in the number of new organizations entering the system, thus leading to a nonlinear relationship between resource availability and organizational density.

There are two reasons to believe that the scarcity of resources may produce not only a levelling off in the number of new organizations entering the system, but perhaps even a decline in organizational density. First, the limits of scarce resources particularly affect the ability of small organizations to compete and survive. In conditions of scarce resources, there is a liability of smallness (Aldrich and Auster, 1986; Freeman, Carroll, and Hannan, 1983), meaning that smaller organizations are less effective than larger organizations, and therefore less viable (as larger organizations can better distribute risk than small organizations, which are more prone to acute shocks in the availability of resources). In conditions of extreme diversity, small ethnic-based parties representing one ethnic group exclusively are not wellsuited to exert much influence over the formation of government and/or policy relative to larger ethnic congress parties, and thus are more likely to exit (or be deserted by voters) in conditions of extreme ethnic diversity.

Second, while specialist organizations like ethnic-based parties are generally bestsuited to compete under most conditions (consistent with the expectation that increases in cleavage diversity produce linear increases in party system fragmentation), more generalist organizations like ethnic congress parties are better-suited under other conditions. According to fitness set theory (Freeman and Hannan, 1983), generalist organizations are better-suited 
than specialist organizations in conditions of coarse grain (i.e. where conditions change slowly, as in the case of social cleavage structures) and high environmental variability (in this case, ethnic diversity). In cases of high levels of ethnic diversity, fitness set theory predicts that more generalist ethnic congress parties are better-suited to compete for voters than more specialist ethnic-based parties.

Applied to ethnic diversity, these organizational ecology theories predict that the relationship between ethnic diversity and party system fragmentation is nonlinear, possibly non-monotonic. As ethnic diversity increases, more resources (ethnic groups) capable of sustaining ethnic-based parties become available, and party system fragmentation increases as a result. In conditions of resource scarcity (i.e. when ethnic diversity increases beyond moderate levels), however, competition for scarce resources increases, and density dependence dynamics begin to produce a nonlinear relationship between resource availability (i.e. ethnic diversity) and organizational density (i.e. party system fragmentation). Drawing from the example of countries in Africa and elsewhere with high levels of ethnic diversity, this creates incentives for larger ethnic congress parties-which more efficiently utilize resources (i.e. mobilize voters) and are thus more capable of winning representation - to form and ultimately displace the myriad smaller ethnic-based parties catering to specific ethnic groups. In such situations, growth in party system fragmentation will level off and possibly even decrease.

Support for this argument can already be found in previous research. Consistent with the notion that the effect of ethnic diversity on conflict should be nonlinear-producing little to no conflict in homogeneous and extremely fragmented systems, but producing significant conflict in cases of moderate diversity (Horowitz, 1985)—recent research shows that electoral volatility in African polities is greatest is countries with moderate levels of ethnic diversity and lowest in countries at the low and high extremes of ethnic diversity (Ferree, 
2010). This argument builds on other research focusing on African systems, maintaining that party system fragmentation should be highest in countries where ethnic diversity is moderate and lowest in countries with either low or high ethnic diversity (Mozaffar, Scarritt, and Galaich, 2003: 389). By referring to theories of organizational ecology, the argument presented here extends this logic beyond African polities to party systems cross-nationally, in line with other research focusing on the non-monotonicity of social diversity more broadly (Stoll, 2013). ${ }^{2}$

Additionally, the argument presented here is in keeping with a large body of research maintaining that party elites play an important role in determining which cleavages will be salient to voting behavior (e.g. Enyedi, 2005; Przeworski and Sprague, 1986; Sartori, 1969; Torcal and Mainwaring, 2003). This can be seen particularly clearly in the context of several African countries, where Posner (2004b) has shown that elites in Malawi and Zambia have rallied the support of two tribes present in both countries in different ways - appealing to ethnic groups using divisive appeals in Malawi but cooperative appeals in Zambia—-that are in keeping with their respective institutional contexts. Consistent with this research, the argument put forth here maintains that elites choose to rally ethnic groups through ethnicbased or ethnic congress parties depending on the size of ethnic groups relative to the overall ethnic diversity of the country.

\section{Research Design}

To test the argument presented above, I examine the relationship between ethnic diversity and party system fragmentation using a well-known data set including elections from around the world (Golder, 2005). The main independent variable is ethnic diversity. Recognizing the concerns with the measurement of ethnic cleavages raised by several authors (Scarritt and Mozaffar, 1999; Mozaffar, Scarritt, and Galaich, 2003; Posner, 2004a), I measure ethnic diversity using a variable that is based upon the Constructivist notion of 
ethnopolitical cleavages, or ethnic identities that are deliberately politicized by political leaders. Specifically, I calculate the effective number of ethnic groups (ENEG) - following the practice of Clark and Golder (2006) — using data on ethnic diversity collected by Fearon (2003). This data set includes all ethnic groups that have, historically, been politicized and comprising at least one percent of the population. Using this variable has the advantage of focusing solely on those ethnic identities that are relevant to politics and ignoring ethnic identities that are not. ${ }^{3}$ In order to capture the nonlinear effects of ethnic cleavages, I include both linear and squared terms for ENEG.

Recognizing that the results may be sensitive to the choice of ethnic cleavage measure (Stoll, 2008), I run robustness tests using alternate measures of ethnic diversity. Using alternative measures of ethnic diversity are particularly important in this case given the possibility that the number of politically relevant ethnic groups may be endogenous to the electoral system in which ethnic groups operate. While this does not appear to be the case, ${ }^{4}$ the results should be robust to the use of alternative variables that do not take into account whether groups are politically relevant or not in calculating ethnic diversity. One such alternative measure $(E L F)$ is the Atlas Narodov Mira measure of ethnolinguistic fractionalization reported in Taylor and Hudson (1972). A second (ENETH) is based on the measure of ethnic fractionalization developed by Alesina et al. (2003). Like with ENEG, these variables are transformed into measures of the effective number of ethnic groups. ${ }^{5}$ Despite theoretical differences in the calculation of these three measures, ENEG is strongly correlated with both $E L F(R=0.77)$ and $\operatorname{ENETH}(R=0.76)$.

The dependent variable, party system fragmentation, is measured using the effective number of electoral parties (ENEP) developed by Laakso and Taagepera (1979), which is calculated using parties' legislative vote shares (for the lower house, where applicable). ${ }^{6}$ This variable is preferable to the effective number of parliamentary parties, which is 
calculated using parties' seat shares instead of vote shares. Because ENEP is calculated using vote shares, it is better able to capture any effects of ethnic cleavages on strategic voting (or the lack thereof) that may reduce party system fragmentation.

Data for this variable is taken from the "Democratic Electoral Systems Around the World, 1946-2000" data set collected by Golder (2005, 2007). This data set includes 867 legislative elections from every continent covering the period from 1946-2000. In keeping with Clark and Golder (2006, 2007), I drop all elections where the "other" category used to calculate ENEP exceeds 15 percent of the vote, as well as all non-competitive elections, all elections using a fused vote in presidential/legislative elections, and countries with majoritarian upper tier electoral systems. Because African elections make up the bulk of the observations with the highest levels of ethnic diversity, it is important to ensure that the African elections included in the Golder (2005) sample used here are representative, or whether the results are conditional upon a non-representative sample of African elections. To address this potential shortcoming, I add to the Golder data set several African elections that were originally collected by Mozaffar, Scarritt, and Galaich (2003) — and recollected by Brambor, Clark, and Golder (2007b) — but not included in Golder (2005) and present both the results of models including and excluding these additional data.

Following the practice of the now-standard interactive model of party system fragmentation developed by Amorim Neto and Cox (1997) and Clark and Golder (2006), I include several additional independent variables. First, and most importantly, is district magnitude $(\log M)$. Following the standard practice in Amorim Neto and Cox (1997) and Clark and Golder (2006), I include the logged functional form of district magnitude. I also include interaction terms between district magnitude and each ethnic diversity variable.

I also include the other control variables from the standard Amorim Neto and Cox model, again using data from Golder $(2005,2007)$. One variable (Upper Tier) measures the 
percentage of seats allocated in an upper tier. Following conventional practice, this variable is interacted with ethnic diversity (both the linear and squared terms). Three other measures accounting for the effects of presidential systems are included. One variable (Proximity) measures the degree of concurrence between presidential and parliamentary elections (a continuous measure ranging from zero - no presidential elections are held — to onepresidential and parliamentary elections are held concurrently). A second measures the effective number of presidential candidates (ENPRES). A third variable is the interaction of Proximity and ENPRES.

Finally, I also control for possible legacy effects resulting from independence movements against colonial rule (through which leaders mobilized as large a base of supporters as possible in order to present a united front: see Hyden, 2006: 28-32) that would lead to smaller party systems in African countries despite high levels of ethnic diversity. This, in turn, might account for any negative relationship between ethnic diversity and party system fragmentation at higher levels of ethnic diversity. To this end, I include a variable that is coded one for African elections and zero otherwise.

I estimate a total of four models. Model 1 presents the results using the full sample of elections. Model 2 is identical to model 1, except that it excludes the African elections collected by Brambor, Clark, and Golder (2007b) to show that the results are not due to the inclusion of these additional cases. To test the robustness of the findings in models 1 and 2, I also estimate models using the alternative measures of ethnic diversity. Model 3 replicates model 1, except that it substitutes $E L F$ for $E N E G$, while model 4 replaces $E N E G$ with ENETH. Following the practice of Clark and Golder (2006), each model is estimated using ordinary least squares linear regression with robust standard errors clustered by country. As the data set includes multiple elections per country, yet ethnic diversity is measured only once per country, treating each observation as independent may produce under-estimated 
standard errors. Clustering the standard errors by country addresses this problem. ${ }^{7}$

In order to determine whether the addition of the squared ethnic diversity term improves model fit, I present the results of two tests. The first is a joint significance test, which tests whether the inclusion of both the linear and squared terms for the ethnic diversity variable are jointly significant. Because the coefficients for the linear and squared terms must be interpreted jointly, interpreting each coefficient separately may yield invalid conclusions about the significance of the effect of ethnic diversity on party system fragmentation. A significant test statistic would provide evidence that the effect of ethnic diversity is nonlinear.

Additionally, I also present the results of likelihood ratio tests comparing each model to a simpler model to determine whether the inclusion of the squared ethnic diversity term (and resulting interactions) significantly improves model fit. To produce this test statistic, I estimate two models - a hypothesized model (which is presented in the results below) and a null model (which is not). For instance, Model 1 (the hypothesized model) replicates the model estimated by Clark and Golder (2006), but includes the squared term for ENEG and the resulting interactions. The hypothesized model takes the following form:

$$
\begin{gathered}
E N E P=\beta_{0}+\beta_{1} \log M+\beta_{2} E N E G+\beta_{3} E N E G^{2}+\beta_{4} L o g M \times E N E G+ \\
\beta_{5} L o g M \times E N E G^{2}+\beta_{6} \text { Upper Tier }+\beta_{7} \text { Upper Tier } \times E N E G+ \\
\beta_{8} \text { Upper Tier } \times E N E G^{2}+\beta_{9} \text { Proximity }+\beta_{10} E N P R E S+\beta_{11}+ \\
\text { Proximity } \times \text { ENPRES }+\beta_{12} \text { Africa }+\in .
\end{gathered}
$$

A null model, which excludes the squared $E N E G$ terms, is also estimated to determine whether the addition of the squared term improves model fit. The null model takes the following form:

$$
\begin{aligned}
E N E P= & \beta_{0}+\beta_{1} \log M+\beta_{2} E N E G+\beta_{4} \log M \times E N E G+\beta_{6} \text { Upper Tier }+ \\
& \beta_{8} \text { Upper Tier } \times \text { ENEG }+\beta_{11} \text { Proximity }+\beta_{10} \text { ENPRES }+
\end{aligned}
$$




$$
\beta_{11} \text { Proximity x ENPRES }+\beta_{12} \text { Africa }+\epsilon \text {. }
$$

Because the null model is nested in the hypothesized model, this test determines the degree to which including the squared terms in the hypothesized model improves model fit over the null model. A significant likelihood ratio statistic would indicate that the inclusion of the squared terms for ENEG (plus the interactions) significantly improves model fit. This, in turn, would provide justification for favoring the hypothesized model over the null model.

\section{Results}

Figure 1 presents a scatterplot of the relationship between party system fragmentation and ethnic diversity with a running mean smoother in order to see the bivariate relationship before proceeding to the results of the regression models. The data show a lack of any clear linear association between party system fragmentation and ethnic diversity, resulting in what - at least initially_appears to be a relatively flat relationship. At the highest levels of ethnic diversity, the relationship becomes negative. ${ }^{8}$ For a point of reference, South Africa appears on the high end of the ethnic diversity scale (with an ENEG value of 8.3). In keeping with the expectations of the organizational ecology approach, party system fragmentation in the two South African elections included in the Golder data set (1994 and 1999) are quite low, much lower than one would expect if the relationship between ethnic diversity and party system fragmentation was truly linear. While there is some evidence that party system fragmentation increases as ethnic diversity increases (at least at low levels of ethnic diversity), the fact party system fragmentation begins to decline starting at the middle range of ethnic diversity suggests the possibility of a nonlinear relationship (especially once controls for the other major determinants of party system fragmentation are added).

\section{Figure 1 about here}

Such a nonlinear association appears in the regression results, which are presented in Table 1. The coefficient for the linear term for ENEG is positive, while the squared term is 
negative. This suggests that the relationship between ethnic diversity and party system fragmentation is initially positive before leveling off or even declining at higher levels of ethnic diversity. Moreover, the results provide evidence for the hypothesis that the linear and squared terms of ENEG are jointly significant. Additionally, accounting for nonlinearity in the effects of ethnic diversity significantly improves model fit. This can be seen in the results of the likelihood ratio test, which shows that the addition of the squared term significantly improves model fit over the null model treating the effects of ethnic diversity as linear.

These findings are not due to any legacy effects particular to the colonial experiences faced by African countries. The nonlinear relationship appears despite the inclusion of a variable to account for possible legacy effects particular to Africa that might account for the negative relationship between ethnic diversity and party system fragmentation at higher levels of ethnic diversity. These findings hold even in model 2, which uses the restricted sample of countries excluding the additional African countries and elections - many of which have high levels of ethnic diversity. As with model 1, the joint significance test statistic demonstrates that the linear and squared terms for ENEG are jointly significant. Also in keeping with model 1 , the inclusion of the squared term significantly improves model fit, as demonstrated by the significant test statistic for the likelihood ratio test. Thus, these results suggest that the relationship between ethnic diversity and party system fragmentation is nonlinear.

\section{Table 1 about here}

The predicted relationship between ethnic diversity and party system fragmentation can be seen more clearly in graphical form. Figure 2 graphically demonstrates the nonlinearity of the predicted relationship between ethnic diversity and party system fragmentation. Specifically, Figure 2 presents the predicted values of ENEP using the results from model 1 across the range of ethnic diversity, holding all control variables constant 
(which assumes a district magnitude of one). As seen in Figure 2, increases in ethnic diversity lead to values of ENEP characteristic of multiparty systems until reaching moderate levels of ethnic diversity. Consistent with fitness set theory (as well as the liability of smallness), however, the relationship between ethnic diversity and ENEP gradually becomes negative at the highest levels of diversity.

\section{Figure 2 about here}

These findings are reinforced by the fact that the relationship between ethnic diversity and party system fragmentation remains nonlinear when using alternative measures of ethnic diversity. This can be seen in models 3 and 4, which use ELF and ENETH as measures of ethnic diversity, respectively. Consistent with the findings in models 2 and 3, the results in models 3 and 4 demonstrate further that the relationship between ethnic diversity and party system fragmentation is nonlinear. While the coefficients for the squared terms for both $E L F$ and ENETH do not reach statistical significance, the result of the joint significance testswhich do reach conventional levels of significance — suggest that the relationships between party system fragmentation and both ELF and ENETH are nonlinear. Additionally, the likelihood ratio test statistics in both models also reach statistical significance. This suggests that the inclusion of a squared term for each model's respective ethnicity variables significantly improves model fit over the null models that do not include the squared terms. In this sense, there is statistical evidence that the relationships between ELF/ENETH and party system fragmentation are nonlinear.

The precise shapes of these relationships can be seen in Figures 3 and 4. Figure 3 presents the predicted relationship between $E L F$ and party system fragmentation using the results from model 3, holding all other variables constant. As in Figure 2, party system fragmentation increases as $E L F$ increases from low to medium values before leveling off at higher values, consistent with the notion of density dependence (though not consistent with 
fitness set theory). Although the uncertainty of these estimates increases dramatically at the highest levels of $E L F$, the nonlinearity in the effect of $E L F$ on party system fragmentation is observed across nearly the entire range of $E L F$. Despite the absence of the drop-off in predicted party system fragmentation at the highest levels of ethnic diversity seen in Figure 2, the fact remains that the relationship between ethnic diversity and party system fragmentation in Figure 3 is nonlinear, and both sets of predicted values are in keeping with an organizational ecology interpretation of ethnic diversity effects.

\section{Figure 3 about here}

Like with Figures 2 and 3, the relationship between ENETH and party system fragmentation is nonlinear. This can be seen more clearly in Figure 4, which presents the predicted values of party system fragmentation using the results from model 4 across the range of ENETH, again assuming district magnitude equals one. As in Figure 2, party system fragmentation increases as ethnic diversity approaches the middle range of diversification, at which party system fragmentation begins to decline - consistent with fitness set theory and the liability of smallness. Although the curve in the predicted values seen in Figure 4 is not nearly as steep across the middle range of ENETH as that observed in Figure 2, and although there is greater uncertainty to these predicted values, the observed relationship is generally consistent with that observed in Figure 2. The fact that the relationship between ethnic diversity and party system fragmentation in each model is consistent with an organizational ecology interpretation demonstrates the robustness of the findings.

\section{Figure 4 about here}

\section{Conclusion}

This paper contributes to the literature by demonstrating that the relationship between ethnic diversity and party system fragmentation is nonlinear. Referring to several organizational ecology theories, increases in ethnic diversity facilitate party system 
fragmentation. However, at extreme levels of ethnic diversity, competition for scarce resources (voters) limits the ability of new parties to form without the exit of existing parties. At the most extreme levels, there is evidence that increased competition leads to a decrease in party system fragmentation, with ethnic congress parties that represent several ethnic groups replacing less competitive ethnic-based parties that represent a single ethnic group. Applied to a broad cross-national sample by building on the now-standard model developed by Amorim Neto and Cox (1997) and Clark and Golder (2006), the results provide considerable support for this hypothesis.

In developing the argument that the effect of ethnic diversity on party system fragmentation is nonlinear, this paper combines insights from research focusing on African party systems with the established literature on the interaction between electoral systems and social cleavages. In doing so, this paper goes some way toward resolving the debate between those maintaining that African party systems are fundamentally different (e.g. Mozaffar, Scarritt, and Galaich, 2003) and those who maintain that African party systems conform to the findings of previous research (e.g. Brambor, Clark, and Golder, 2007a). According to the argument and findings presented here, African party systems (and other countries with high levels of ethnic diversity) are not fundamentally different from party systems elsewhere. Instead, the relationship between ethnicity and party system fragmentation is nonlinear because the extreme diversity seen in many African countries is not able to sustain smaller ethnic-based parties, which results in less party system fragmentation.

The findings presented here may present an important revision to a considerable body of research (e.g. Duverger, 1954; Ordeshook and Shvetsova, 1994; Amorim Neto and Cox, 1997; Clark and Golder, 2006; Singer and Stephenson, 2009), which has assumed (intentionally or not) that the effects of cleavages are linear. Because the results presented here suggest that the relationship between ethnic diversity and party system fragmentation is 
nonlinear, and because most of the studies examining the interaction of cleavages and electoral system proportionality have used measures of ethnic diversity to measure the effects of social cleavages, future studies must re-evaluate the conclusions reached by earlier research. By failing to account for the nonlinearity of ethnic (and potentially other) cleavages, it is quite possible that cleavage effects have been underestimated in previous research, and the effects of electoral systems in constraining the impact of cleavages have been overstated, at least to some extent. The fact that party system fragmentation in many plurality systems significantly exceeds the two-party predictions made by Duverger (1954), illustrate the importance of this point. In light of the findings presented here, many of the conclusions reached by this literature need to be revisited in order to determine whether this is the case.

Finally, the logic behind these findings may be applicable to other measures of cleavage diversity. Like with ethnic diversity, religious diversity may produce incentives for religious group leaders to coalesce behind one party banner in religiously diverse countries in the same way that ethnic groups coalesce behind ethnic congress parties in extremely ethnically diverse countries. One need only look to the United States for an example of this, where high religious diversity has produced a coalition of religiously observant voterseroding the longstanding differences between Protestants and Catholics — under the banner of the Republican Party (e.g. Layman, 2001). This suggests that the effects of other cleavages on party system fragmentation may be nonlinear as well. Future research, therefore, is needed to determine whether the diversity of other cleavages has similar effects. 


\section{References}

Aldrich, H.E., Auster, E.R. 1986. Even dwarfs started small: Liabilities of age and size and their strategic implications. In: Staw, B.M., Cummings, L.L. (Eds.), Research in Organizational Behavior, Vol. 8. JAI, Greenwich, Connecticut, pp. 165- 198.

Alesina, A., Devleeschauwer, A., Easterly, W., Kurlat, S., Wacziarg, R., 2003. Fractionalization. Journal of Economic Growth 8 (2), 155-194.

Amorim Neto, O., Cox, G.W., 1997. Electoral Institutions, Cleavage Structures, and the Number of Parties. American Journal of Political Science 41(1), 149-174.

Beck, N., Katz, J.N., 1995. What to Do (And Not to Do) With Time-Series Cross-Section Data. American Political Science Review 89 (3), 634-647.

Birnir, J., Gurr, T., Hultquist, A.S., Jonas, A., 2012. Minorities at Risk IV Dataset. Center for International Development and Conflict Management, University of Maryland. Accessed at: 〈http://www.cidcm.umd.edu/mar/>.

Bogaards, M., 2004. Counting parties and identifying dominant party systems in Africa. European Journal of Political Research 43 (2), 173-197.

Bogaards, M., 2008. Dominant Party Systems and Electoral Volatility in Africa: A Comment on Mozaffar and Scarritt. Party Politics, 14 (1), 113-130.

Brambor, T., Clark, W.R., Golder, M., 2007a. Are African Party Systems Different? Electoral Studies 26 (2), 315-323.

Brambor, T., Clark, W.R., Golder, M., 2007b. Replication data for: Are African Party Systems Different? http://hdl.handle.net/1902.1/10559

UNF:3:EiJkB9ZQmL0qN82HMuE3Ew== Matt Golder [Distributor] V1 [Version]

Chandra, K. 2011. What is an ethnic party? Party Politics 17 (2), 151-169.

Clark, W.R., Golder, M., 2006. Rehabilitating Duverger's Theory: Testing the Mechanical and Strategic Modifying Effects of Electoral Laws. Comparative Political Studies 39 (6), 679-708.

Clark, W., Golder, M., 2007. Replication data for: Rehabilitating Duverger's Theory: Testing the Mechanical and Strategic Modifying Effects of Electoral Laws. http://hdl.handle.net/1902.1/10477 UNF:3:9vZjXJDKPmggOHufBr6UKw== Matt Golder [Distributor] V1 [Version]

Delacroix, J., Carroll, G.R. 1983. Organizational foundings: An ecological study of the newspaper industries of Argentina and Ireland. Administrative Science Quarterly 28 (2), 274-291.

Duverger, M., 1954. Political Parties. Wiley, New York.

Enyedi, Z., 2005. The role of agency in cleavage formation. European Journal of Political Research 44 (5), 697-720. 
Erdmann, G., Basedau, M., 2008. Party systems in Africa: Problems of categorizing and explaining party systems. Journal of Contemporary African Studies 26 (3), 241-258.

Fearon, J.D., 2003. Ethnic and Cultural Diversity by Country. Journal of Economic Growth 8 (2), 195-222.

Ferree, K.E., 2010. The Social Origins of Electoral Volatility in Africa. British Journal of Political Science 40 (4), 759-779.

Freeman, J., Carroll, G.R., Hannan, M.T. 1983. The liability of newness: Age dependence in organizational death rates. American Sociological Review 48 (5), 692-710.

Freeman, J., Hannan, M.T. 1983. Niche width and the dynamics of organizational populations. American Journal of Sociology 88(6), 116-145.

Golder, M., 2005. Democratic Electoral Systems Around the World, 1946-2000. Electoral Studies 24 (1), 103-121.

Golder, M., 2007. Replication data for: Democratic Electoral Systems Around the World, 1946-2000, http://hdl.handle.net/1902.1/10479

UNF:3:Tck3h2JpUzohauPCbNIm5w== Matt Golder [Distributor] V1 [Version]

Hannan, M.T., Freeman, J., 1977. The Population Ecology of Organizations. American Journal of Sociology 82 (5), 929-64.

Hannan, M.T., Carroll, G.R., 1992. Dynamics of Organizational Populations: Density, Competition, and Legitimation. Oxford University Press, Oxford.

Horowtz, D.L., 1985. Ethnic Groups in Conflict: Theories, Patterns, and Policies. University of California Press, Berkeley.

Hyden, G., 2006. African Politics in Comparative Perspective. Cambridge University Press, New York.

Kuenzi, M., Lambright, G., 2001. Party System Institutionalization in 30 African Countries. Party Politics 7(4), 437-468.

Laakso, M., Taagepera, R., 1979. "Effective” Number of Parties: A Measure with Application to West Europe. Comparative Political Studies 12 (1), 3-27.

Layman, G.C., 2001. The Great Divide: Religious and Cultural Conflict in American Party Politics. Columbia University Press, New York.

Lindberg, S., 2007. Institutionalization of party systems? Stability and fluidity among legislative parties in Africa's democracies. Government and Opposition 42 (2), 215241.

Lowery, D., Gray, V. 1995. The Population Ecology of Gucci Gulch, or the Natural Regulation of Interest Group Numbers in the American States. American Journal of Political Science 39 (1), 1-29.

Lowery, D., Otjes, S., Gherghina, S., Van Witteloostuijn, A., Peli, G., Brasher, H., 2010. 
Unpacking Log M: Toward a More General Theory of Party System Density. American Journal of Political Science 54 (4), 921-935.

Lowery, D., Witteloostuijn, A., Peli, G., Brasher, H., Otjes, S., \& Gherghina, S., 2013. Policy agendas and the births and deaths of political parties. Party Politics 19 (3), 381-407.

Mozaffar, S., Scarritt, J.R., Galaich, G., 2003. Electoral Institutions, Ethnopolitical Cleavages, and Party Systems in Africa's Emerging Democracies. American Political Science Review 97 (3), 379-390.

Mozaffar, S., Scarritt, J.R., 2005. The Puzzle of African Party Systems. Party Politics 11 (4), 399-421.

Nownes, A.J., 2004. The Population Ecology of Interest Group Formation: Mobilizing for Gay and Lesbian Rights in the United States, 1950-98. British Journal of Political Science 34 (1), 49-67.

Nownes, A.J., 2010. Density Dependence in the Population of Transgender Interest Groups in the United States, 1964-2005. Social Science Quarterly 91 (3), 689-703.

Ordeshook, P. C., Shvetsova, O. V., 1994. Ethnic Heterogeneity, District Magnitude, and the Number of Parties. American Journal of Political Science 38 (1), 100-123.

Piombo, J., 2005. Political Parties, Social Demographics, and the Decline of Ethnic Mobilization in South Africa, 1994-99. Party Politics 11 (4), 447-470.

Posner, D.N., 2004a. Measuring Ethnic Fractionalization in Africa. American Journal of Political Science 48 (4), 849-863.

Posner, D.N., 2004b. The Political Salience of Cultural Difference: Why Chewas and Tumbukas Are Allies in Zambia and Adversaries in Malawi. American Political Science Review 98 (4), 529-545.

Powell, G.B., 2000. Elections as Instruments of Democracy: Majoritarian and Proportional Visions. Yale University Press, New Haven.

Przeworski, A., Sprague, J., 1986. Paper Stones: A History of Electoral Socialism. University of Chicago Press, Chicago.

Sartori, G. (1969) From the Sociology of Politics to Political Sociology. In: Lipset, S.M. (Ed.) Politics and the Social Sciences. Oxford University Press, New York, pp. 65100.

Scarritt, J., Mozaffar, S., 1999. The Specification of Ethnic Cleavages and Ethnopolitical Groups for the Analysis of Democratic Competition in Africa. Nationalism and Ethnic Politics 5 (1), 82-117.

Singer, M.M., Stephenson, L.B., 2009. The political context and Duverger's Theory: Evidence at the district level. Electoral Studies 28 (3), 480-491.

Singh, J.V., Lumsden, C.C., 1990. Theory and Research in Organizational Ecology. Annual Review of Sociology, 16, 161-95. 
Stoll, H., 2008. Social Cleavages and the Number of Parties: How the Measures You Choose Affect the Answers You Get. Comparative Political Studies 41 (11), 1439-1465.

Stoll, H., 2013. Changing Societies, Changing Party Systems. Cambridge University Press, New York.

Stretesky, P.B., Huss, S., Lynch, M.J., 2012. Density dependence and environmental justice organizations, 1970-2008. Social Science Quarterly 49 (3), 343-351.

Taagepera, R., 1997. Effective number of parties for incomplete data. Electoral Studies 16 (2), 145-151.

Taylor, C., Hudson, M. 1972. World handbook of political and social indicators (2nd Ed.). Yale University Press: New Haven.

Torcal, M., Mainwaring, S., 2003. The Political Recrafting of Social Bases of Party Competition: Chile, 1973-95. British Journal of Political Science 33 (1), 55-84. 
Table 1: The Nonlinear Effects of Ethnic Diversity on Party System Fragmentation (ENEP)

\begin{tabular}{|c|c|c|c|c|}
\hline & \multicolumn{4}{|c|}{ Models } \\
\hline $\begin{array}{c}\text { Ethnic Diversity } \\
\text { Measures }\end{array}$ & 1 & 2 & 3 & 4 \\
\hline ENEG & $\begin{array}{l}0.51 * * \\
(0.14)\end{array}$ & $\begin{array}{l}0.49 * \\
(0.24)\end{array}$ & & \\
\hline $\mathrm{ENEG}^{2}$ & $\begin{array}{c}-2.08 * * \\
(0.63) \\
\end{array}$ & $\begin{array}{c}-3.78^{* *} \\
(1.37) \\
\end{array}$ & & \\
\hline ELF & & & $\begin{array}{l}0.33^{*} \\
(0.20)\end{array}$ & \\
\hline ELF $^{2}$ & & & $\begin{array}{l}-1.29 \\
(1.62)\end{array}$ & \\
\hline ENETH & & & & $\begin{array}{l}0.39 * \\
(0.20)\end{array}$ \\
\hline ENETH $^{2}$ & & & & $\begin{array}{l}-2.20 \\
(1.43)\end{array}$ \\
\hline Control Variables & & & & \\
\hline $\log M$ & $\begin{array}{c}0.26 \\
(0.21)\end{array}$ & $\begin{array}{l}-0.51 \\
(0.46)\end{array}$ & $\begin{array}{c}0.21 \\
(0.34)\end{array}$ & $\begin{array}{c}0.28 \\
(0.22)\end{array}$ \\
\hline $\begin{array}{c}\operatorname{LogMx} \\
\text { Ethnic Diversity }\end{array}$ & $\begin{array}{c}0.17 \\
(0.15)\end{array}$ & $\begin{array}{l}1.07 * \\
(0.50)\end{array}$ & $\begin{array}{c}0.32 \\
(0.32)\end{array}$ & $\begin{array}{c}0.17 \\
(0.18)\end{array}$ \\
\hline $\begin{array}{l}\qquad \operatorname{LogMx} \\
\text { Ethnic Diversity }^{2}\end{array}$ & $\begin{array}{l}-2.40^{*} \\
(1.38)\end{array}$ & $\begin{array}{c}-0.25^{* *} \\
(0.10)\end{array}$ & $\begin{array}{l}-5.37 \\
(4.19)\end{array}$ & $\begin{array}{l}-1.85 \\
(1.46)\end{array}$ \\
\hline Upper Tier & $\begin{array}{l}3.18 \\
(2.43)\end{array}$ & $\begin{array}{l}-0.14 \\
(4.78)\end{array}$ & $\begin{array}{l}5.48 * * \\
(2.09)\end{array}$ & $\begin{array}{l}1.04 \\
(3.84)\end{array}$ \\
\hline $\begin{array}{c}\text { Upper Tier x } \\
\text { Ethnic Diversity }\end{array}$ & $\begin{array}{l}-0.29 \\
(1.47) \\
\end{array}$ & $\begin{array}{l}1.55 \\
(4.09) \\
\end{array}$ & $\begin{array}{l}-2.64^{*} \\
(1.38) \\
\end{array}$ & $\begin{array}{c}2.36 \\
(3.59) \\
\end{array}$ \\
\hline $\begin{array}{c}\text { Upper Tier x Ethnic } \\
\text { Diversity }^{2}\end{array}$ & $\begin{array}{l}-0.07 \\
(0.15)\end{array}$ & $\begin{array}{c}0.52 \\
(0.63)\end{array}$ & $\begin{array}{c}0.26 \\
(0.20)\end{array}$ & $\begin{array}{l}-0.78 \\
(0.68)\end{array}$ \\
\hline Proximity & $\begin{array}{c}-3.27 * * \\
(0.52)\end{array}$ & $\begin{array}{c}-3.39 * * \\
(0.50)\end{array}$ & $\begin{array}{c}-3.13 * * \\
(0.50)\end{array}$ & $\begin{array}{l}-2.91 * * \\
(0.50)\end{array}$ \\
\hline ENPRES & $\begin{array}{l}0.33^{*} \\
(0.15) \\
\end{array}$ & $\begin{array}{l}0.31^{*} \\
(0.15)\end{array}$ & $\begin{array}{l}0.36^{*} \\
(0.16) \\
\end{array}$ & $\begin{array}{l}0.37 * \\
(0.15) \\
\end{array}$ \\
\hline Proximity x ENPRES & $\begin{array}{l}0.76^{* *} \\
(0.23)\end{array}$ & $\begin{array}{l}0.74 * * \\
(0.22)\end{array}$ & $\begin{array}{l}0.74 * * \\
(0.20)\end{array}$ & $\begin{array}{l}0.67 * * \\
(0.21)\end{array}$ \\
\hline Africa & $\begin{array}{l}-1.25^{*} \\
(0.63)\end{array}$ & $\begin{array}{c}0.38 \\
(1.23)\end{array}$ & $\begin{array}{l}-0.44 \\
(0.50)\end{array}$ & $\begin{array}{l}-0.89^{*} \\
(0.42) \\
\end{array}$ \\
\hline Constant & $\begin{array}{l}2.37 * * \\
(0.32)\end{array}$ & $\begin{array}{l}2.45 * * \\
(0.44)\end{array}$ & $\begin{array}{l}2.37 * * \\
(0.35)\end{array}$ & $\begin{array}{l}2.37 * * \\
(0.30)\end{array}$ \\
\hline Joint Significance & $6.24 * *$ & $4.00 *$ & $7.23 * *$ & $3.38^{*}$ \\
\hline LR Test & $24.01 * *$ & $47.65 * *$ & $9.10 *$ & $16.85^{* *}$ \\
\hline $\mathrm{R}^{2}$ & 0.34 & 0.36 & 0.34 & 0.38 \\
\hline $\mathrm{n}$ & 589 & 555 & 609 & 692 \\
\hline
\end{tabular}

$* \mathrm{p}<0.05, * * \mathrm{p}<0.01$, one-tailed tests. Entries represent regression coefficients with robust standard errors clustered by country in parentheses. The following coefficients are multiplied by 100 in order to improve readability: $E N E G^{2}, E L F^{2}, E N E T H^{2}, L o g M$ x Ethnic Diversity ${ }^{2}$, Upper Tier, Upper Tier x Ethnic Diversity, and Upper Tier x Ethnic Diversity ${ }^{2}$. "Joint Significance" refers to the results of an F test that the linear and squared terms for the respective ethnic diversity variable included in each model are jointly significant. "LR Test" refers to the results of a likelihood ratio test comparing the model including $E N E G$ and $E N E G^{2}$ (or $E L F$ and $E L F^{2} / E N E T H$ and $E N E T H^{2}$ ) with a nested model excluding the squared term and resulting interactions. The results for a control variable for a significant outlier - Comoros - are excluded from model 4. 
Figure 1: Scatterplot of the Relationship between Ethnic Diversity (ENEG) and Party System Fragmentation (ENEP)

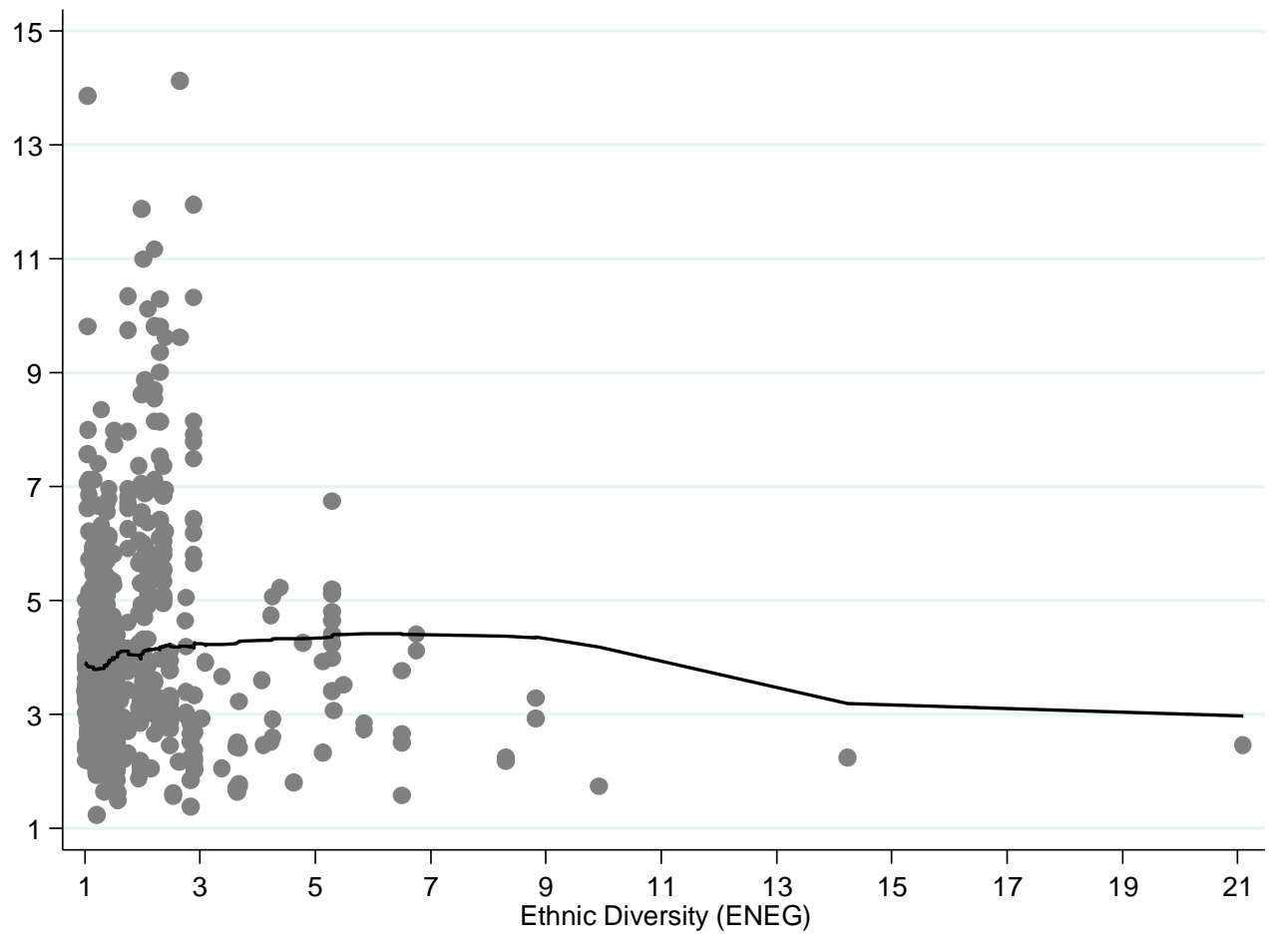

Note: the black line is a running mean smoother with an $80 \%$ bandwidth. 
Figure 2: The Predicted Relationship between Ethnic Diversity (ENEG) and Party System Fragmentation $(E N E P)$

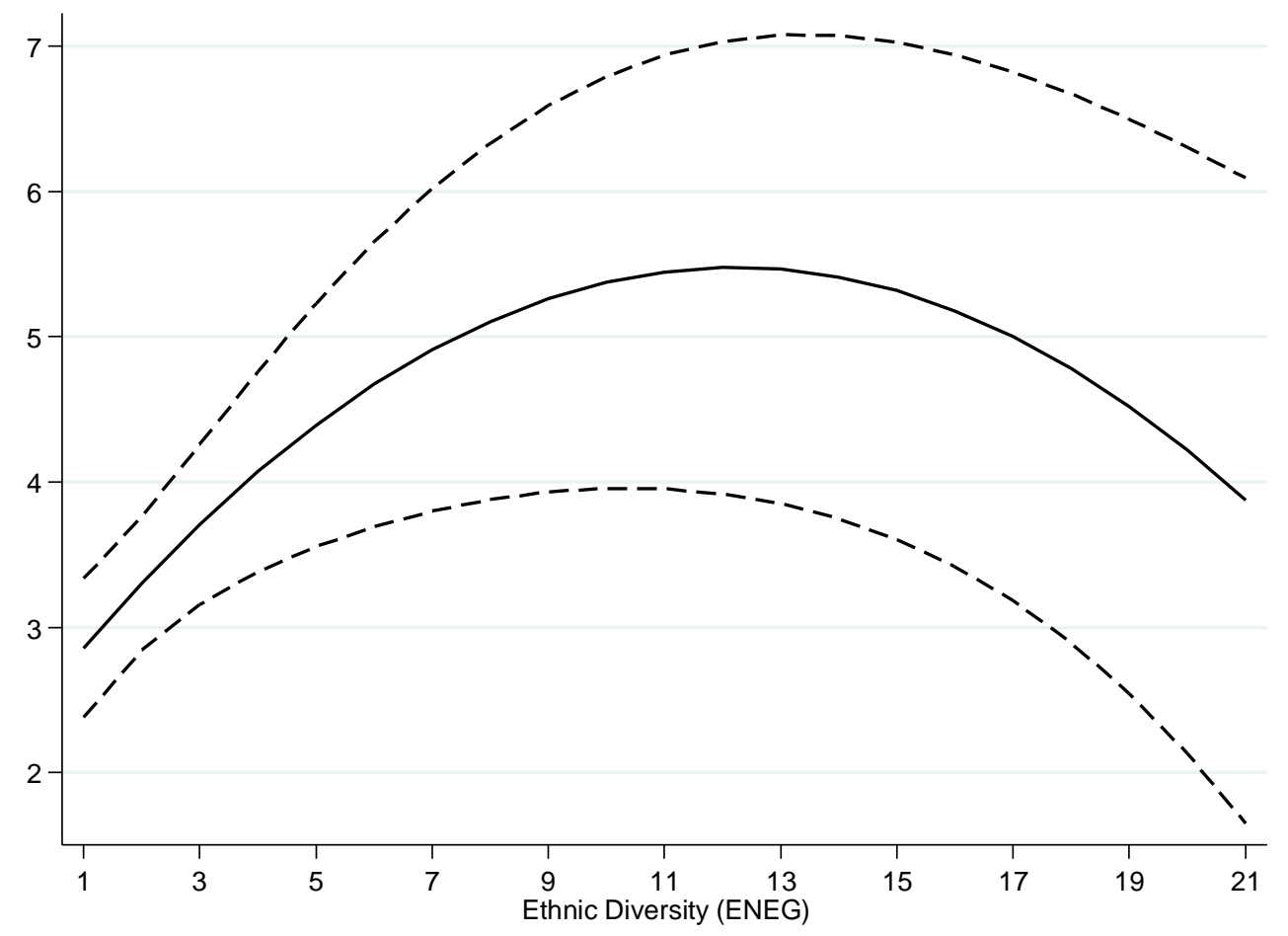

Note: dashed lines represent $95 \%$ confidence intervals. 
Figure 3: The Predicted Relationship between Ethnic Diversity $(E L F)$ and Party System Fragmentation $(E N E P)$

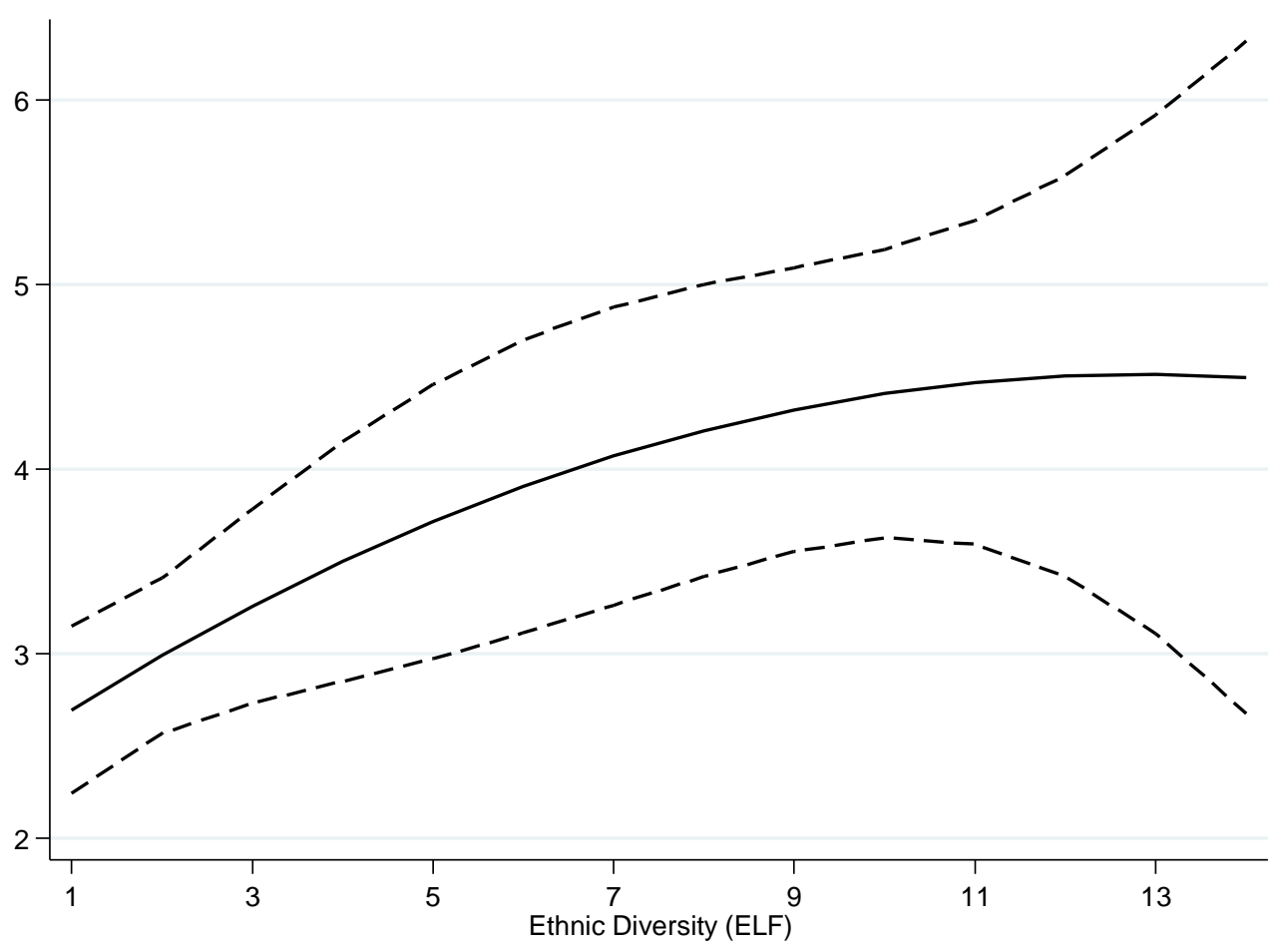

Note: dashed lines represent 95\% confidence intervals. 
Figure 4: The Predicted Relationship between Ethnic Diversity (ENETH) and Party System Fragmentation (ENEP)

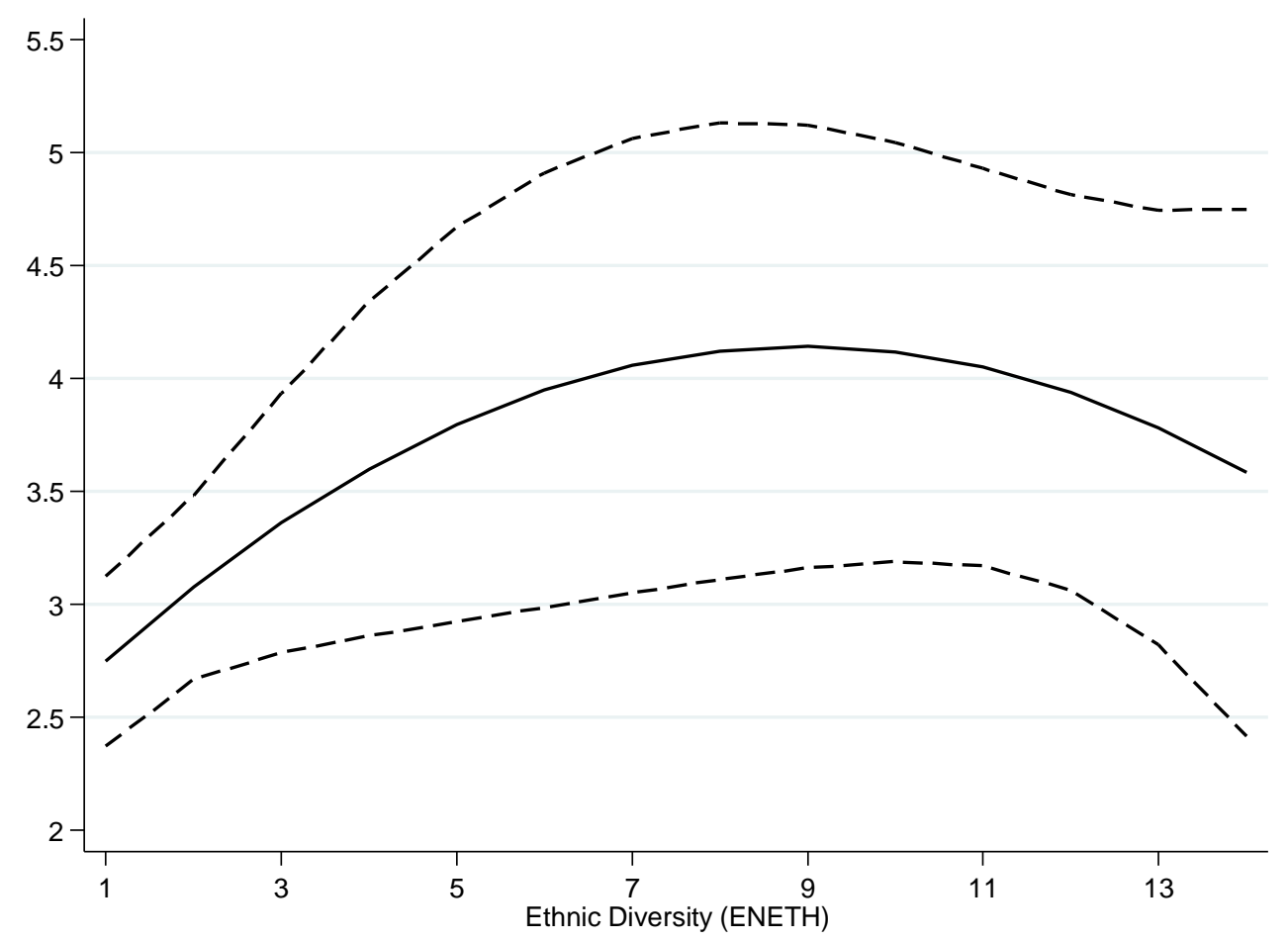

Note: dashed lines represent $95 \%$ confidence intervals. 


\section{Supplementary File}

This supplementary file presents the results of robustness tests re-estimating all four models presented in Table 1 in the main text. As noted in footnote 8 in the main text, these robustness tests serve to assuage concerns that the results for the ethnic diversity variables presented are due to the presence of outlier effects. As seen in Figure 1 in the main text, with only a handful of countries at the highest levels of each ethnic diversity variable, one has to wonder if the findings of nonlinear association between ethnic diversity and party system fragmentation are due to the presence of these outlying values of ethnic diversity.

To provide such assurances, I re-estimated each model presented in Table 1 in the main text replacing the linear and squared measures of ethnic diversity with a single variable measuring ethnic diversity that uses the (natural) logged functional form. The argument presented in the main text holds that ethnic diversity should be positively associated with party system fragmentation in roughly linear fashion at lower levels of ethnic diversity; however, this effect should begin to level off—-possibly reaching a plateau — at the highest levels of ethnic diversity. In keeping with the organizational ecology approach (particularly the notion of density dependence), the data transformation produced when using the logged functional form assumes a sigmoid-shaped relationship between ethnic diversity and party system fragmentation. Because this sigmoid-shaped relationship is in keeping with organizational ecology theories (see Lowery et al., 2010), positive and significant coefficients for each logged ethnic diversity variable would provide evidence supporting the organizational ecology argument presented in the main text.

The results of the robustness tests-re-estimating each model in Table 1 using the logged functional form - appear in Table S.1, which replicates Table 1 in the main text with the exception that the linear and squared measures of ethnic diversity have been replaced with their logged functional forms. As the results show, ethnic diversity is positively and 
significantly associated with party system fragmentation in all four models. These results confirm the findings presented in the main text.

Examining the predicted values of party system fragmentation graphically illustrates this point even further. Figures S.1-S.3 present the predicted values of party system fragmentation using the results from models 1, 3, and 4 in Table S.1. To facilitate comparison with Figures 2-4 in the main text, and to observe the nonlinearity in the relationship between ethnic diversity and party system fragmentation implied by the use of the logged functional form, the values in Figures S.1-S.3 have been back-transformed (i.e. I take the exponential values of ethnic diversity in order to return ethnic diversity to its original scale). Consistent with the expectations of the organizational ecology approach (especially the notion of density dependence), party system fragmentation increases as ethnic diversity increases at lower levels of party system fragmentation when using all three measures of ethnic diversity. However, this increase begins to level off quickly beginning at medium values of ethnic diversity, and flattens out nearly entirely at the highest levels of ethnic diversity.

In sum, these results confirm the findings presented in the main text. Both here and in the main text, the results show that the relationship between ethnic diversity and party system fragmentation is nonlinear. While there is some evidence from the results presented in the main text that party system fragmentation may drop off at the highest levels of ethnic diversity, as is the case in Figures 2 and 4 (findings that are not supported in this Supplementary File), the differences between Figures 2 and 4 versus Figures S.1-S.3 may be due simply to the small number of observations at the highest levels of ethnic diversity. The bigger point is that both sets of findings - whether party system fragmentation levels off or declines at the highest levels of ethnic diversity — show that the relationship between ethnic diversity and party system fragmentation is nonlinear. More importantly, both sets of 
findings are consistent with the organizational ecology theories discussed in the main text. Thus, there is strong, robust evidence that the relationship between ethnic diversity and party system fragmentation is nonlinear and that this nonlinear relationship can be explained by an approach rooted in an understanding of the organizational ecology of ethnic cleavages. 
Table S.1: The Nonlinear Effects of Ethnic Diversity on Party System Fragmentation (ENEP) Using Logged Measures of Ethnic Diversity

\begin{tabular}{|c|c|c|c|c|}
\hline & \multicolumn{4}{|c|}{ Models } \\
\hline $\begin{array}{c}\text { Ethnic Diversity } \\
\text { Measures }\end{array}$ & 1 & 2 & 3 & 4 \\
\hline $\ln (\mathrm{ENEG})$ & $\begin{array}{l}1.05^{* *} \\
(0.30)\end{array}$ & $\begin{array}{l}1.05 * * \\
(0.39)\end{array}$ & & \\
\hline $\ln (\mathrm{ELF})$ & & & $\begin{array}{c}0.69^{* *} \\
(0.25)\end{array}$ & \\
\hline $\ln (\mathrm{ENETH})$ & & & & $\begin{array}{l}0.62 * \\
(0.31)\end{array}$ \\
\hline Control Variables & & & & \\
\hline $\log M$ & $\begin{array}{c}0.47 * * \\
(0.10)\end{array}$ & $\begin{array}{l}0.44 * * \\
(0.10)\end{array}$ & $\begin{array}{c}0.53 * * \\
(0.10)\end{array}$ & $\begin{array}{l}0.44 * * \\
(0.09)\end{array}$ \\
\hline $\begin{array}{c}\operatorname{LogMx} x \\
\text { Ethnic Diversity }\end{array}$ & $\begin{array}{l}-0.04 \\
(0.14)\end{array}$ & $\begin{array}{c}0.07 \\
(0.19)\end{array}$ & $\begin{array}{l}-0.03 \\
(0.21)\end{array}$ & $\begin{array}{l}0.06 \\
(0.18)\end{array}$ \\
\hline Upper Tier & $\begin{array}{l}0.04 * * \\
(0.01)\end{array}$ & $\begin{array}{l}0.04 * * \\
(0.01)\end{array}$ & $\begin{array}{l}0.03 * * \\
(0.01)\end{array}$ & $\begin{array}{l}0.03 * * \\
(0.01)\end{array}$ \\
\hline $\begin{array}{c}\text { Upper Tier } \mathrm{x} \\
\text { Ethnic Diversity }\end{array}$ & $\begin{array}{l}-0.03^{*} \\
(0.01)\end{array}$ & $\begin{array}{l}-0.03 \\
(0.02)\end{array}$ & $\begin{array}{c}-0.03^{* * *} \\
(0.01)\end{array}$ & $\begin{array}{c}-0.03^{* * *} \\
(0.01)\end{array}$ \\
\hline Proximity & $\begin{array}{c}-3.30 * * \\
(0.52)\end{array}$ & $\begin{array}{c}-3.38^{* *} \\
(0.55)\end{array}$ & $\begin{array}{c}-3.17 * * \\
(0.51)\end{array}$ & $\begin{array}{c}-2.95 * * \\
(0.51)\end{array}$ \\
\hline ENPRES & $\begin{array}{l}0.33^{*} \\
(0.16) \\
\end{array}$ & $\begin{array}{l}0.34^{*} \\
(0.16) \\
\end{array}$ & $\begin{array}{l}0.36^{*} \\
(0.16) \\
\end{array}$ & $\begin{array}{l}0.37 * * \\
(0.15) \\
\end{array}$ \\
\hline Proximity x ENPRES & $\begin{array}{c}0.78 * * \\
(0.23) \\
\end{array}$ & $\begin{array}{l}0.79 * * \\
(0.24)\end{array}$ & $\begin{array}{l}0.76^{* *} \\
(0.21)\end{array}$ & $\begin{array}{l}0.70 * * \\
(0.21)\end{array}$ \\
\hline Africa & $\begin{array}{l}-1.28 * \\
(0.59) \\
\end{array}$ & $\begin{array}{l}-1.07 \\
(1.07)\end{array}$ & $\begin{array}{l}-0.51 \\
(0.50)\end{array}$ & $\begin{array}{l}-0.92^{*} \\
(0.43) \\
\end{array}$ \\
\hline Constant & $\begin{array}{c}2.66 * * \\
(0.25)\end{array}$ & $\begin{array}{l}2.64 * * \\
(0.28)\end{array}$ & $\begin{array}{l}2.59 * * \\
(0.24)\end{array}$ & $\begin{array}{l}2.69 * * \\
(0.20)\end{array}$ \\
\hline $\mathrm{R}^{2}$ & 0.33 & 0.31 & 0.33 & 0.37 \\
\hline $\mathrm{n}$ & 589 & 555 & 609 & 692 \\
\hline
\end{tabular}

$* \mathrm{p}<0.05, * * \mathrm{p}<0.01$, one-tailed tests. Entries represent regression coefficients with robust standard errors clustered by country in parentheses. The results for a control variable for a significant outlier-Comoros-are excluded from model 4. 
Figure S.1: The Predicted Relationship between Ethnic Diversity (ENEG) and Party System Fragmentation (ENEP)

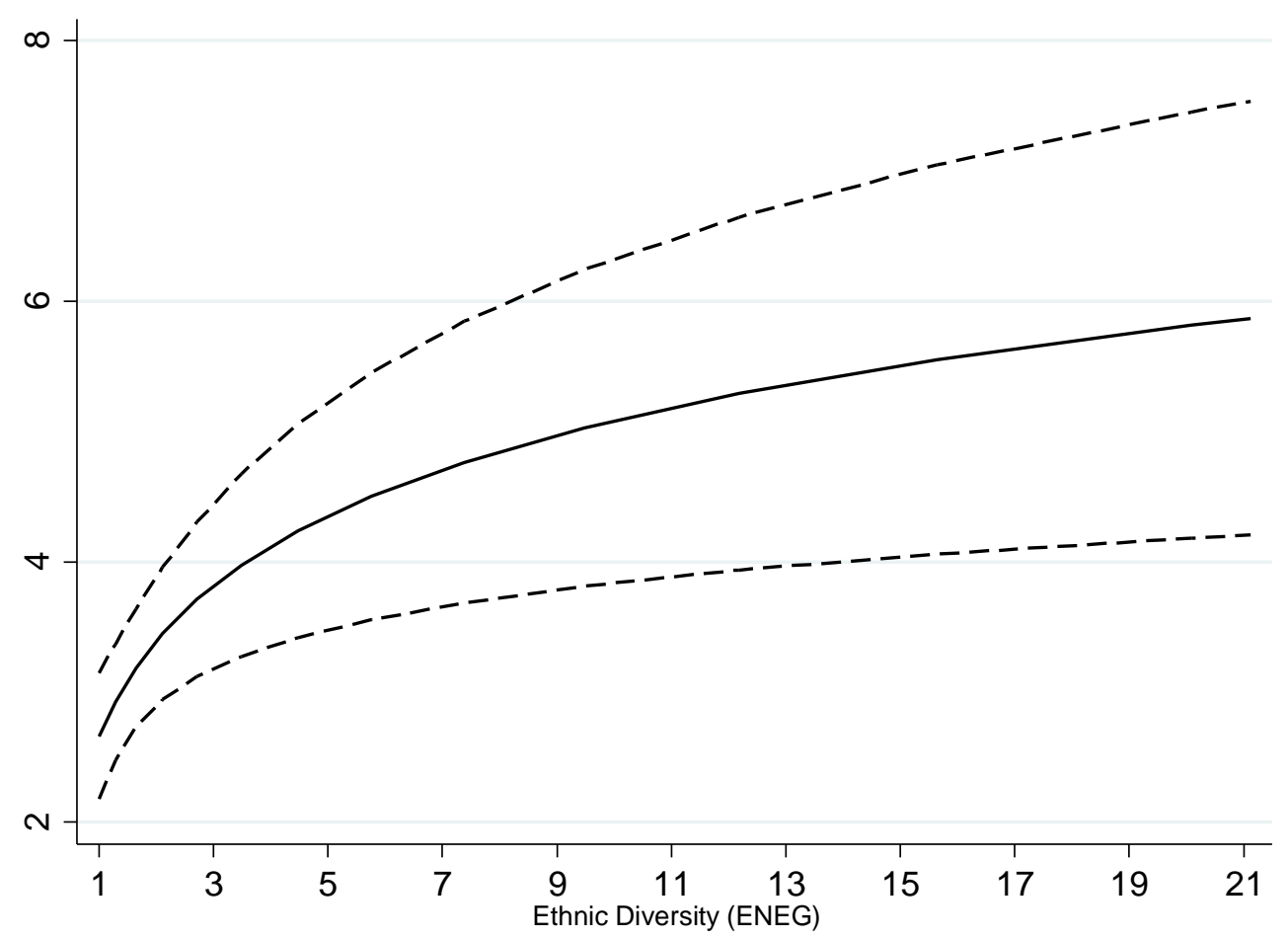

Note: dashed lines represent $95 \%$ confidence intervals. ENEG has been back-transformed in order to show the nonlinearity between ethnic diversity and party system fragmentation. 
Figure S.2: The Predicted Relationship between Ethnic Diversity (ELF) and Party System Fragmentation $(E N E P)$

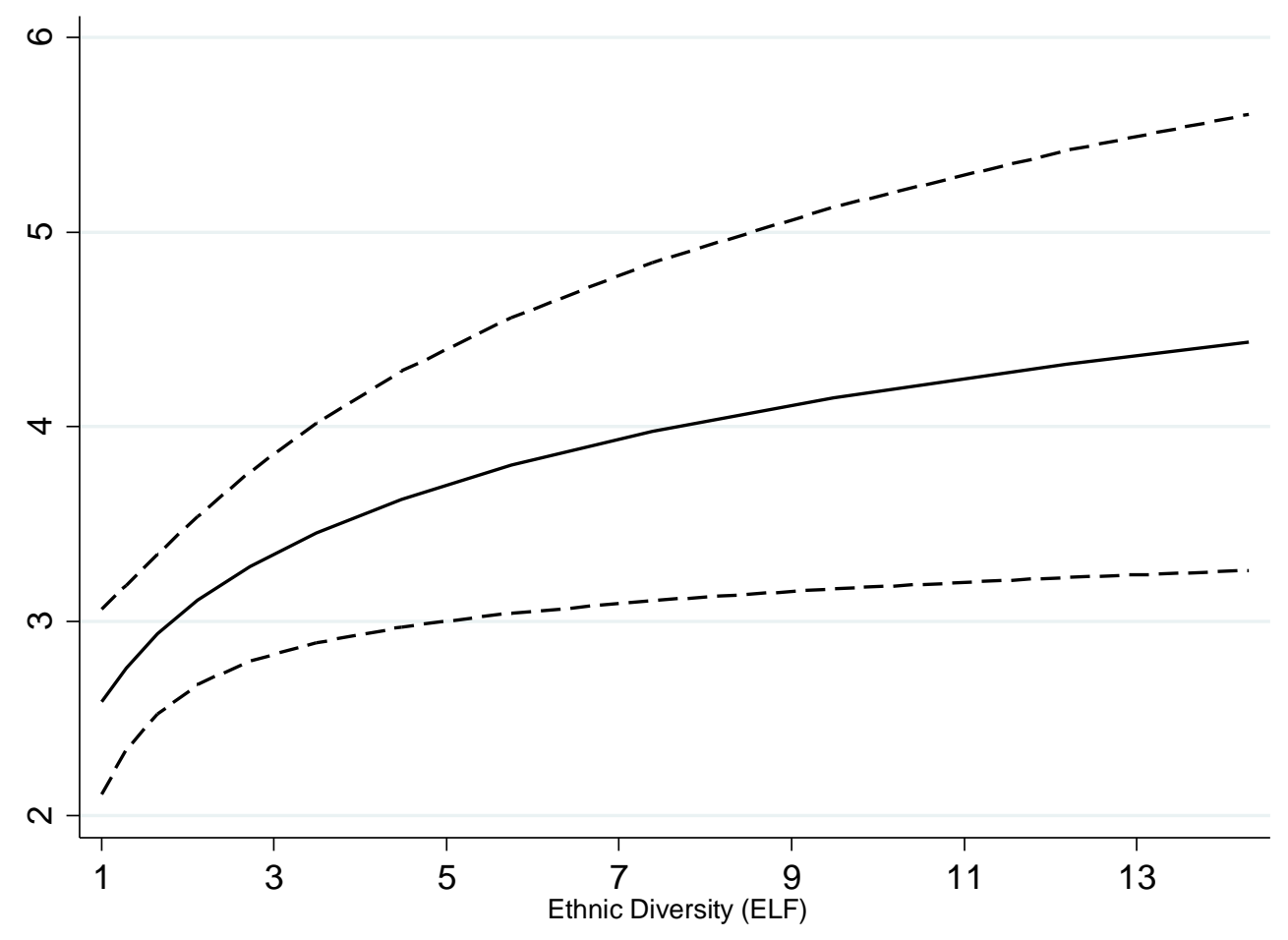

Note: dashed lines represent $95 \%$ confidence intervals. $E L F$ has been back-transformed in order to show the nonlinearity between ethnic diversity and party system fragmentation. 
Figure S.3: The Predicted Relationship between Ethnic Diversity (ENETH) and Party System Fragmentation $(E N E P)$

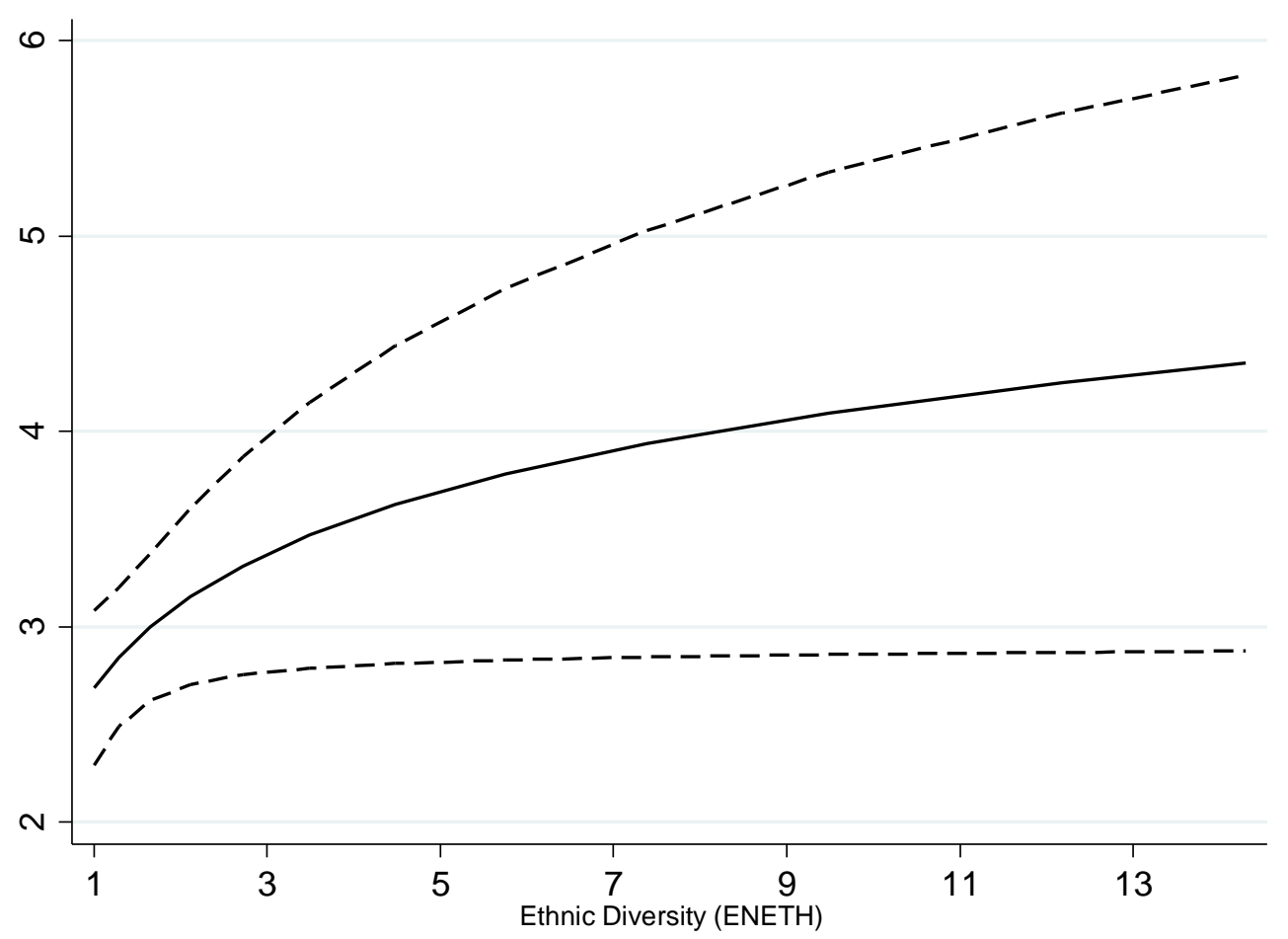

Note: dashed lines represent $95 \%$ confidence intervals. ENETH has been back-transformed in order to show the nonlinearity between ethnic diversity and party system fragmentation. 
${ }^{1}$ Because of the difficulty in defining the concept of ethnic parties (see Chandra, 2011), I use the term "ethnic-based party" to refer to a party that appeals to (and wins support from) one ethnic group exclusively (or nearly so) and the term "ethnic congress party" to refer to parties that mobilize voters and win support from multiple ethnic groups.

${ }^{2}$ While Stoll (2013) finds that the effects of social diversity on party system fragmentation vary considerably across the range of social diversity, the present study is focused on one particular cleavage. As such, the predictions made here with regard to the non-monotonic effects of social diversity may be particular to ethnic diversity.

${ }^{3}$ Although it would have been desirable to include another variable measuring the degree to which each ethnic group is concentrated in certain regions-in keeping with Mozaffar, Scarritt, and Galaich (2003) — such data are not available. As noted by Fearon (2003: 196), while the Minorities at Risk (Birnir et al., 2012) data set includes data on the degree of concentration for each ethnic group, the definition and coverage of ethnic groups focuses only on ethnic groups “at risk" and/or facing discrimination (or engaging in discrimination), and thus truncates the sample of ethnic diversity.

${ }^{4}$ While ethnic diversity provides incentives for the formation of multiple parties, these parties would only receive seats in PR systems, and thus elites in majoritarian systems have fewer incentives to try to activate multiple ethnic identities. If ethnic identification — and, in turn, levels of ethnic diversity — was determined primarily by the electoral system, then we would expect more ethnic diversity in PR systems than majoritarian systems. In fact, ethnic diversity is significantly greater in majoritarian systems than in PR systems (as determined by t-tests).

${ }^{5}$ This is done using the following formulas: $1 /\left(1-\mathrm{F}_{\mathrm{ELF}}\right)$ and $1 /\left(1-\mathrm{F}_{\text {Alesina et al. }}\right)$, where $\mathrm{F}_{\mathrm{ELF}}$ is the ethno-linguistic fractionalization measure reported by Taylor and Hudson (2003) and $\mathrm{F}_{\text {Alesina et }}$ 
al. is the ethnic fractionalization measure developed by Alesina et al. (2003).

${ }^{6}$ Taagepera (1997) notes potential problems of inference arising from the calculation of $E N E P$ with an "other parties" category (and offers a correction for this problem). Following the practice of Clark and Golder (2006), I also apply this correction.

${ }^{7}$ In order to address possible contemporaneous correlation in the standard errors, I also estimated models using panel-corrected standard errors (see Beck and Katz, 1995) by treating election years as the units of analysis so that elections are spaced at regular intervals (instead of irregularly spaced intervals when using country years as the units of analysis). The results using this approach are even more statistically significant than the findings presented here.

${ }^{8}$ Recognizing the outlier potential caused by countries with outlying values of ethnic diversity, I re-estimated each model presented in Table 1 using (natural) log-transformed values of ethnic diversity instead of the quadratic functional form used here. The results using these alternative measures can be seen in the Supplementary File. Because the logged functional form implies the very sigmoid-shaped curve expected by organizational ecology theories (on this point, see also Lowery et al., 2010), the results of these robustness tests only serve to reinforce the substantive conclusions drawn here. 